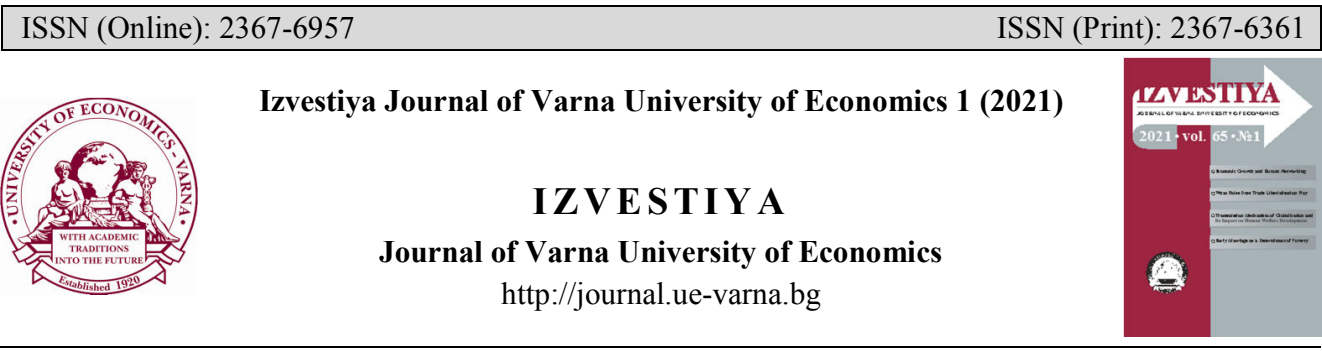

\title{
CAPITAL FLOWS AND ECONOMIC GROWTH: WHAT ROLES DOES TRADE LIBERIALISATION PLAY?
}

\author{
Soliu ADEGBOYEGA ${ }^{1}$, Temidayo AKINBOBOLA ${ }^{2}$, \\ Felix AJAYI ${ }^{3}$
}

${ }^{1}$ Department of Economics, Faculty of Social Sciences, Olabisi Onabanjo University, Ogun State, Nigeria. E-mail: adegboyega.soliu@oouagoiwoye.edu.ng.

${ }^{2}$ Department of Economics, Faculty of Social Sciences, Obafemi Awolowo University, Osun State, Nigeria.

${ }^{3}$ Department of Economics, Faculty of Social Sciences, Olabisi Onabanjo University, Ogun State, Nigeria.

JEL: F20, F43, C32, J13

Key words:

Capital inflows, Trade

Liberalisation, Economic Growth, Time Series,

ARDL.

\begin{abstract}
This paper explores by re-examining to what extent trade liberalisation has contributed to the capital inflows (both the private capital inflows and public capital inflow) on economic growth; and their interactive relationship in Nigeria between 1985 and 2018. Time series for each of the variables were collected from secondary sources on yearly basis, extracted from World Development Indicators (WDI) and the variables were measured as percentage of GDP, while Autoregressive Distributed Lag (ARDL) technique is used to show the extent to which the variables were co-integrated and established that both private capital inflows and public capital inflows with the helps of trade liberalization inhibited economic growth in Nigeria. The study further revealed that the coefficient of error correction was negative and highly significant, as well as establishing long-term cointegration. Also, our study affirms partial existence of Bhagwati's hypothesis. Hence, the government needs to restructure and reengineer most of its trade policies, in order to significantly impact various forms of foreign capital inflows, and subsequently enhance economic growth by creating an enabling economic environment to facilitate adequate inflows of capital inflows.
\end{abstract}

(C) 2021 University of Economics - Varna

Citation: ADEGBOYEGA, S., AKINBOBOLA, T., AJAYI, F. (2021). Capital Flows and University of Economics, 65 (1), pp. 26 - 44. DOI: 10.36997/IJUEV2021.65.1.26 
S. Adegboyega, T. Akinbobola, F. Ajayi. Capital Flows and Economic Growth:

What Roles Does Trade Liberialisation Play?

\section{Introduction}

The urge to close the gap between investment and savings in most developing countries becomes imperative, since they are plagued with capital-scarce resources that are needed for their economy to derive. However, neoclassical and endogenous growth theories emphasize that in a capital-scarce economy FDI promotes economic growth both in quantity and in physical investment output (Lucas 1988; Grosman \& Helpman 1991; Baro \& Salai-I-Martin 1995). Similarly, foreign direct investment is providing long-term capital through new technology, management skills and marketing skills, which in turn increases economic growth through the creation of jobs, increased management skills, technology diffusion, and innovation (see Asiedu, 2002; Paugel, 2007).

From the literature, two major strands of theoretical models have been exploited and have underlined that foreign capital inflows promotes growth in a capital-scarce economy. The neoclassical economic growth theory postulates, among others, that any sustained level of growth is due solely to technology. Solow (1988) stated that it is a growth in which the permanent rate of growth of output per unit of labour input is independent of the saving (investment) rate and depends entirely on the rate of technological progress in the broadest sense. This conclusion flows from a particular kind of equation, called an aggregate production function, and follows from the way Solow combined this function with the fact of depreciation and population growth. On the other hand, endogenous growth theory on the other hand, emphasizes that economic growth is primarily the result of endogenous and not exogenous forces. That is, investment in human capital, innovation, and knowledge ( $\&$ \&) are significant contributors of growth. The focus of this theory is on positive externalities and spillover effects of a knowledge-based economy which lead to overall economic development.

However, trade and capital flows are conceived as the two engines of globalization and are very important factors in the economic growth process. Hence, the relationship between trade openness, capital formation, foreign direct investment and economic growth has appeared to be positive historically. Empirical studies have produced mixed results on how trade openness and FDI intertwined with growth, both in countries and across the countries (Borensztien et. al, 1998; Mansouri 2005). Thus, Pahlavani et al, (2005) have concluded that FDI as well as trade promote economic development.

In a contrary view Balasubramanyam et al. (1996); Borensztein et al., (1998); De Mello (1999); Lipsey, (2000); and Xu, (2000) all argued that FDI and trade could 
adversely influence growth in some countries. Also, Kormendi and Meguire (1985), Barro (1991), Levine and Renalt (1992) concluded that the rate of formation of physical capital affects the rate of economic growth in a country. Kendrick (1993) also stated that capital formation on its own does not result in economic prosperity, but instead the transfer of capital redistribution from the less efficient to the more efficient sectors enhances economic growth. Hence, substantial number of studies documented a positive relationship between foreign capital and economic growth (Osinubi \& Amaghionyeodiwe, 2010; Khadraoui, 2012; Odhiambo, 2011), and more so other studies have equally observed either a negative relationship or ambiguous effect of capital inflows on economic growth (see Akinlo, 2004; Burke \& AhmadiEsfahani 2006; Alfaro et. al., 2001; Shahbaz \& Rahman 2010). In another studies conducted by Akinlo (2003); Alege and Ogun (2005) only related the effects of trade to different macroeconomic indicators and sectors of various world economies whereas Uwatt (2004); Orji, Uche and Ilori (2014) relate theirs on growth of less developed countries-LDCs including ECOWAS Members state. However, studies conducted by Abdulai and Jaquet (2002); Akanyo and Ajie (2015); Olaleye (2015); Adegboyega, Odusanya and Popoola (2017) and Saibu (2014) were among the few country specific. But, Adegboyega, et. al., (2017) and Saibu (2014) both gave different submissions on the impact of trade, capital flow and economic growth in Nigeria using a common approach but different theoretical proposals.

Recently, with the use of Pooled Mean Group (PMG) econometric technique, Mowlaei (2018) investigated how different forms of foreign capital inflows (FCIs) including FDI, personal remittances and ODA affect economic growth in 26 top African countries between 1992 and 2016. His result showed that all three forms of FCIs have positive and significant effects on economic growth in the long and short run. However, the personal remittances had the most impact on economic growth in both long and short run. The study therefore, recommends that policy makers should design and implement appropriate fiscal, monetary and trade policies in order to create and improve an enabling environment to attract FCIs as a supplementary source of domestic investment. Also, Adegboyega et. al., (2017) while studying the relation and role of capital flight, especially FDI and aid, through the implementation of the general aggregate production function (APF), using the annual data set covering the period 1980 to 2015. Autoregressive distribution lag (ARDL) cointegrating approach was used to test the linkage between capital flow and trade while the static OLS estimation was used to determine the role played by the variables in relation to economic growth. Foreign direct investment showed a negative relationship, while trade openness, capital stock as measured by gross fixed 
S. Adegboyega, T. Akinbobola, F. Ajayi. Capital Flows and Economic Growth:

What Roles Does Trade Liberialisation Play?

capital formation over GDP and labour growth rates showed a positive connection. Furthermore, they revealed that there exists a long-run co-integration relationship between the interest variables of the overall production function. The unidirectional causality from all independent to economic growth has also been identified. Similarly, Shuaib (2014) examined the effects of capital inflow on economic growth and also investigated the role of trade openness in foreign capital inflow/growth nexus in Nigeria. The study used the methodology of Principal Component Analysis (PCA) to derive a single index that shows the quantity and efficiency of traditional capital influx steps, along with openness to trade. The time series properties of the data were analyzed and the bound testing Autoregressive Distributed Lag (ARDL) was used to evaluate time series data. His result showed that when dealing with trade openness, the inflow of capital had a significant effect on economic growth and thus supported the theory of modernity and empirically supports the complementary capital flow and foreign policy.

For the case of Senegalese economy, Adams and Klobodu (2017) investigated the role played by capital flows in the process of growth in the long run. The time frame for the study ranged from 1970 to 2014 and the ARDL serves basis for estimating the long- and short-run relationships between the underlying economic variables. They found from the results that remittances drive the process of economic growth in Senegal in the long run. On the contrary, external debt has a negative impact on economic growth. Their result further revealed that no long run association exists between inflows aid and growth. However, the result of the Quandt-Andrews breakpoint test indicates that year 1991 is the most likely breakpoint location for the remittances-growth model. Sequel to the outcome of the econometrics analysis, the study recommended that both government and other policy makers should focus attention on creating enabling economic environment to facilitate adequate inflows of remittances in order to foster development.

Similarly, relying on autoregressive distributed model (ARDL) for estimating the dynamic model, Waweru and Ochieng (2017) explored the immediate and lagged effects of the various forms of capital flows such as FDI portfolio flows and other investments capital on economic growth in Kenya between 1984 and 2014. They observed from the results that FDI and portfolio investments flows have a negative impact on the GDP growth rate, but their impact is not statistically significant at the conventional 5 percent level of significance. However, other investments flows such as corporate, financial institutions, general government borrowings and remittances from the diaspora all have a significant positive impact on GDP growth rate. However, utilising three-stage least squares (3SLS) which corrects for the 
endogeneity of the dependent variables as well as the trade openness variable in the structural equations, and generate unbiased and efficient estimates, Brun and Gnangnon (2017) investigated whether trade openness could be an important driver of financing for development flows, notably development aid (ODA), foreign direct investment (FDI) inflows, and government public revenue, depending on an unbalanced panel dataset comprising 125 countries, of which 37 are Least Developed Countries (LDCs). Their result revealed that trade openness is consistently associated with higher government public revenue, as well as higher development aid inflows. Also, trade openness exerts no significant impact on FDI inflows over the entire sample, but does influence negatively FDI inflows in LDCs and positively FDI inflows in non-LDCs

Olaleye (2015) investigated the effect of capital flows on economic Growth in Nigeria and attempted to offer evidence on the relationship among real gross domestic product (rgdp), foreign direct investment netflow (fdin), exchange rate (excr) and trade openness (trap). Using Johansen Cointegration test, his study revealed the presence of long-run relationship among the cointegrating variables. The model showed that the statistical significance of all variables with the exception of the FDIN was verified by the exogeneity test. The Granger causality test shows both the existence of one and twoway causality among certain variables. Similarly, Akanyo et. al., (2015) examined the impact of capital flows on the Nigerian economy in a liberalized environment between 1981 and 2012. Using Johansen cointegration test, the paper demonstrated that net capital flow influenced the level of economic growth in Nigeria significantly and positively. Their results indicated that a 1 per cent net increase in capital flows, particularly FDI, would increase economic growth by 3 percent in Nigeria, while the 40 percent growth rate for FDI, which has a constant outflow, would lead to a 40 percent increase in economic growth. A number of factors such as high corruption, political instability, lack of confidence in domestic currencies, etc. leading to capital excess in the economy can explain the lower elasticity of the net flows.

In Tunisia for instance, Hassen and Anis (2012) investigated the impact of foreign direct investment on the economic growth of the host country. The fact has led to this study that, despite the free trading system, the free movement of capital and of commodities, and the global economy has proved to be fully sophisticated and increasingly complex. The study covers the period from 1975 to 2009 for which data were available. Estimates and tests based on modern analysis of time series (stationary tests, co-integration tests, error correction models) model based on that of Akinlo (2004) was constructed. Their findings indicate that FDI may help boost the long term economic growth cycle, and that FDI has a long-term connection to the 
S. Adegboyega, T. Akinbobola, F. Ajayi. Capital Flows and Economic Growth:

What Roles Does Trade Liberialisation Play?

variables and that it has a positive relationship to the economic growth which is consistent with Sackey et. al., (2012).

In view of the above, it could be concluded that empirical literature in relations to the theoretical paradoxical of the nexus between capital flow and economic growth is inconclusive as some are in support of positive relationship while on the other hand, some reported a negative relationship and besides, some could not trace any relationship or submitted a weak relationship. As such, this difference in divergency of views could be traced to methodology, data selection and analytical tools used in the analysis. In addition this could be attributed to country specific in relations to environment, institutional arrangement, economical, political settings and technological progress in the receiving country of interest of foreign direct investment. Equally, most studies reviewed have only looked at capital inflows without distinguishment which are private capital inflows or public capital inflow, however each of this inflow serves different purpose within the context of economic growth in a country. Also, to the best of our knowledge in Nigeria, no study has yet to test the Bhagwati's hypothesis, which states that any gains from foreign capital inflows on TFP would surely be dependent on the volume of trade openness of a particular host country.

Therefore, this study tries to reconstruct to what extent trade liberalisation contributed to capital inflows-economic growth nexus in Nigeria between 1985 and 2018, periods of post-financial liberalisation as well as to the Structural Adjusted Program transition policies (SAP). However, the policy of the SAP included the deregulation of the economy, the introduction of new industrial policy in 1989, the establishment of the Nigeria Investment Promotion Commission (NIPC) in early 1990s, and the signing of Bilateral Investment Treaties (BITs) in the late 1990s. Moreover, the technique of co-integration (ARDL) is used for the testing of the longrun equilibrium of variables (Pesaran, Shin \& Smith 2001). The rest of the analysis is structured as follows: Section 2 entails methodological examination of the literature, model specification, variable definitions, and data sources. Section 4 reports empirical findings of results and finally concludes the study.

\section{Methodology}

Following research by Feder (1983); Pagano (1993); Saibu (2014) and Adegboyega et. al., (2017), which is a prototype of the endogenous growth model that hinges on the AK model of Solow growth model. Hence, the study adapted the total output feature through the general aggregate production function (APF) model, which is specified as: 


$$
\mathrm{Y}_{\mathrm{t}}=\mathrm{A}_{\mathrm{t}} \mathrm{K}_{\mathrm{t}}^{\alpha}
$$

where $Y_{t}$ denotes the aggregate production of the economy (real GDP per capita) at time $t, A_{t}$, is the total factor productivity (TFP) and $K_{t}$, is the capital stock. Lipsey (2001) observed that the impact of foreign capital inflows on economic growth possibly operates through TFP denoted as A in equation (1). In addition, Bhagwati's hypothesis stated that, any gains from foreign capital inflows on TFP would surely be dependent on the volume of trade openness of a particular host country. By endogenising all variable of interest, such that is TFP is a function of FDI and TRAD. Hence:

$$
\mathrm{A}_{\mathrm{t}}=f\left(\mathrm{TRAD}_{\mathrm{t}}, \mathrm{FDI}_{\mathrm{t}}\right.
$$

Similarly, capital flows in the form of financial capital according to the Lucas paradox and Heckscher-Ohlin-Mundell model can lead to capital and trade substitutability. Therefore, equation (2) can be re-written as

$$
\mathrm{A}_{\mathrm{t}}=f\left(\mathrm{TRAD}_{\mathrm{t}}, \mathrm{FDI}_{\mathrm{t}}, \mathrm{REM}_{\mathrm{t}}, \mathrm{ODA}_{\mathrm{t}}\right)
$$

Substituting equation (3) into equation (1), we have

$$
\mathrm{Y}_{\mathrm{t}}=\operatorname{TRAD}^{\sigma}{ }_{\mathrm{t}}, \mathrm{FDI}^{\omega}{ }_{\mathrm{t}} \operatorname{REM}_{\mathrm{t}}^{\gamma} \mathrm{ODA}_{\mathrm{t}}^{\gamma} \mathrm{K}_{\mathrm{t}}^{\alpha}
$$

Where: $\sigma, \omega, \gamma$ and $\beta$ were constant elasticity coefficient of output with respect to $\mathrm{TRAD}_{\mathrm{t}}, \mathrm{FDI}_{\mathrm{t}} \mathrm{REM}_{\mathrm{t}} \mathrm{ODA}_{\mathrm{t}}$ and $\mathrm{K}_{\mathrm{t}}$.

Taking the natural logs of both sides of equation (4), we have below an explicit estimable equation as:

$$
\operatorname{InY}=\mathrm{a}+\omega \operatorname{InFDI}_{\mathrm{t}}+\delta \operatorname{InREM}_{\mathrm{t}}+\gamma \operatorname{InODA}_{\mathrm{t}}+\beta \operatorname{InTRAD}_{\mathrm{t}}+\varepsilon_{\mathrm{t}}
$$

The intention of the study is to examine the interaction between trade liberalisation and various forms of capital inflows in the country thereby testing the Bhagwati's hypothesis. Hence, the model is estimated as follows:

$$
\begin{aligned}
& \text { PCGDP }_{t}=a_{o}+\omega_{1} \operatorname{InFDI}_{t}+\delta_{2} \operatorname{InREM}_{t}+\gamma_{3} \operatorname{InODA}_{t}+\beta_{4} \operatorname{InTRAD}_{t}+ \\
& \pi_{5} \operatorname{InFDI} * T R A D_{t}+\sigma_{6} \operatorname{InREM} * T R A D_{t}+\varphi_{7} \operatorname{InODA} * T R A D_{t}+\varepsilon_{t}
\end{aligned}
$$

where $a_{o}$ is the constant parameter, and $\varepsilon_{\mathrm{t}}$ is the white noise error term.

The measure for capital inflows includes disaggregated variables such net official development assistance (ODA), personal remittance received and foreign direct investment. The variables are measured as percentage of GDP and are extracted from World Development Indicators. 
S. Adegboyega, T. Akinbobola, F. Ajayi. Capital Flows and Economic Growth:

What Roles Does Trade Liberialisation Play?

The choice of disaggregated measure of capital inflows is more appropriate as each specific type of flow is unique, especially in terms of taxes couple with the efficiency in tax collection and different degree of expropriation (Aizenman and Noy, 2009) and trade openness (TRAD) is measured, as (imports + exports)/GDP (Kargbo, 2012 and Shuaib, 2014) are used to capture the trade liberalisation. PCGDP is measure as the per capita GDP for Nigeria. However, the expected sign of the parameters $\omega_{1}, \delta_{2}, \gamma_{3}$ and $\beta_{4}$ are all expected to be positive (i.e $>0$ ), while the coefficient of the interaction between trade liberalisation and capital inflows $\pi_{5}, \sigma_{6}$ and $\varphi_{7}$ will depend on the capital inflows type that is considered and confirm the position of the Bhagwati's hypothesis.

In an attempt to determine the short and long run relationships between capital flows and economic growth. Equation (5) is altered by the implementation of Pesaran et. al., (1991) system for ARDL:

$$
\begin{aligned}
& \Delta P C G D P_{t}=a_{o}+\omega_{1} \operatorname{InFDI}_{t}+\delta_{2} \operatorname{InREM}_{t}+\gamma_{3} \operatorname{InODA}_{t}+\beta_{4} \operatorname{InTRAD}_{t}+ \\
& \gamma_{5} \operatorname{InFDI} * T R A D_{t}+\sigma_{6} \operatorname{InREM} * T R A D_{t}+\varphi_{7} \operatorname{InODA} * T R A D_{t}+\omega_{1} \Delta \operatorname{InFDI} I_{t}+ \\
& \delta_{2} \Delta \operatorname{InREM} M_{t}+\beta_{3} \Delta \operatorname{InOD} A_{t}+\alpha_{4} \Delta \operatorname{InTRAD} D_{t}+\gamma_{5} \Delta \operatorname{InFDI} * T R A D_{t}+ \\
& \sigma_{6} \Delta \operatorname{InREM} * T R A D_{t}+\varphi_{7} \Delta \operatorname{InODA} * T R A D_{t}+\varepsilon_{t}
\end{aligned}
$$

$\Delta$ denotes the first difference operator.

Using ARDL allows variables of different optimal lags to be employed and as claimed by Bahmani-Oskooee and Hegerty (2010), and Kyophilavong et al (2013), unlike the conventional Johansen cointegration approach which requires variables to be integrated of the same order, the ARDL bound tests for cointegration can be applied to variables irrespective of whether they are $\mathrm{I}(0)$ or I(1) or mutually cointegrated. This methodology, in addition to other benefits already mentioned, allows researchers to explore correct dynamic structure. It allows for inferences on long-run estimates which are not possible under alternative co-integration procedures. Finally, ARDL model can accommodate greater number of variables in comparison to other Vector Autoregressive (VAR) models (Pesaran \& Shin 1995). For a country specific study, the usual problem of data comparability, measurement issue and consistency do not arise in this case. All the variables are as defined in and sourced from the World Development Index (WDI) while all variables are expressed in log form. 


\section{Results, Outcomes and Conclusion of the study}

Table 1

\section{Descriptive Analysis}

\begin{tabular}{|l|r|r|r|r|r|}
\hline & \multicolumn{1}{c|}{ PCGDP } & ODA & \multicolumn{1}{c|}{ FDI } & REM & \multicolumn{1}{c|}{ TRAD } \\
\hline Mean & 1747.065 & $1.48 \mathrm{E}+09$ & 3.247438 & 4.082271 & 71.23769 \\
\hline Median & 1353.024 & $4.41 \mathrm{E}+08$ & 2.75 & 3.646945 & 71.7944 \\
\hline Maximum & 3425.569 & $1.27 \mathrm{E}+10$ & 10.8 & 13 & 91.30857 \\
\hline Minimum & 1151.126 & $1.20 \mathrm{E}+08$ & 0.637 & 0.00859 & 61.74737 \\
\hline Std. Dev. & 588.8969 & $2.47 \mathrm{E}+09$ & 2.235872 & 3.558349 & 7.00735 \\
\hline Skewness & 0.911484 & 3.448845 & 1.764182 & 1.015085 & 1.157933 \\
\hline Kurtosis & 2.98555 & 15.26881 & 6.176392 & 3.360817 & 4.16646 \\
\hline Jarque-Bera & 4.431232 & 264.1357 & 30.05175 & 5.669035 & 8.965149 \\
\hline Probability & 0.109086 & 0 & 0 & 0.058747 & 0.011304 \\
\hline Sum & 55906.1 & $4.73 \mathrm{E}+10$ & 103.918 & 130.6327 & 2279.606 \\
\hline Sum Sq. Dev. & 10750786 & $1.89 \mathrm{E}+20$ & 154.9728 & 392.5173 & 1522.191 \\
\hline Observations & 32 & 32 & 32 & 32 & 32 \\
\hline
\end{tabular}

Source: Authors' Computation (2019).

Table I shows the descriptive statistics of the variables employed in the analysis. The data revealed the mean values of economic growth (PCGDP), net official developmental assistance (ODA), foreign direct investment (FDI), remittance received (REM) and trade liberalisation (TRAD) as 1747.0, 0.000000014, 3.247, 4.082, and 71.237, compared to the median values of 1353.0, 0.00000044, 2.75, 3.646 and 71.79 respectively. However, all the variable of interest was positively skewed. In addition, the Kurtosis result ODA, FDI, REM and TRAD were leptokurtic, since the p-values were more than 3 while only PCGDP was platykurtic, since the p-value is less than 3 .

Furthermore, the Jarque-Bera statistics shows that the series is normally distributed since the p-values of all the series are not statistically significant at $5 \%$ level. Thus, we have to accept the alternate hypothesis that says each variable is normally distributed. 
S. Adegboyega, T. Akinbobola, F. Ajayi. Capital Flows and Economic Growth:

What Roles Does Trade Liberialisation Play?

Table 2

\section{Correlation Matrix}

\begin{tabular}{|l|r|r|r|r|r|}
\hline & \multicolumn{1}{|c|}{ PCGDP } & \multicolumn{1}{c|}{ ODA } & \multicolumn{1}{c|}{ FDI } & \multicolumn{1}{c|}{ REM } & \multicolumn{1}{c|}{ TRAD } \\
\hline PCGDP & 1 & & & & \\
\hline ODA & 0.3640954 & 1 & & & \\
\hline FDI & -0.383432 & -0.0577534 & 1 & & \\
\hline REM & 0.427749 & 0.68221164 & 0.14197913 & 1 & \\
\hline TLIB & 0.7121768 & 0.26129057 & -0.1050075 & 0.568757 & 1 \\
\hline
\end{tabular}

Source: Authors' Computation (2019).

Table 2 presents the correlation coefficients of gross domestic product per capita (PCGDP) net official developmental assistance (ODA), foreign direct investment (FDI), remittance (REM) and Trade liberalisation (TRAD). The results show that none of the correlation coefficient in the table was perfectly correlated.

Table 3

\section{Relationship between Capital Flows, Economic Growth and Trade Liberalisation}

\begin{tabular}{|l|r|r|r|}
\hline \multicolumn{1}{|c|}{ Variables } & \multicolumn{1}{c|}{ Model I } & \multicolumn{1}{c|}{ Model II } & \multicolumn{1}{c|}{ Model III } \\
\hline C & $-0.3196(-0.2886)$ & $3.7698(4.8633)^{* *}$ & $15.778(3.8283)^{* *}$ \\
\hline LODA & $0.1253(4.8372)^{* *}$ & & $-0.2508(3.5171)^{* *}$ \\
\hline LFDI & $-0.1727(-48958)^{* *}$ & & $0.2478(3.6566)^{* *}$ \\
\hline LREM & $0.01702(1.2730)$ & & \\
\hline LTRAD & $1.2545(4.4958)^{* *}$ & & $0.2477(4.2578)^{* *}$ \\
\hline FDI*TRAD & & $-0.1639(-3.6182)^{* *}$ & $0.00048(1.7954)$ \\
\hline ODA $^{*}$ TRAD & & $0.1780(6.0295)^{* *}$ & $-15.5948(3.7871)^{* *}$ \\
\hline REM $^{*}$ TRAD & & $0.0255(1.4988)$ & $-0.0036(-3.9658)^{* *}$ \\
\hline R $^{2}$ & & 0.79 & 0.92 \\
\hline Adjusted R & & 0.76 & 0.90 \\
\hline F-Stat & 0.86 & & $52.51(0.0000)$ \\
\hline D.W & $48.7858(0.000)$ & $35.37(0.0000)$ & 1.72 \\
\hline
\end{tabular}

Source: Authors' Compilation (2019).

Value in (**) implies t-Statistics@ 5\% significant level

Note@Model I: Without Interative variables

II: Only Interactive variables

III: With Interactive variables 
Table 3 presented the estimates of interactive behaviour of trade liberalisation on capital inflows and economic growth using ordinary least square.

From model I, it was revealed that only the Remittances were considered to be negligible among the portion of capital inflows, whereas the amount of FDI and official development assistance was important at 5\%. Trade liberalization (TRAD) also proved to be relevant at a level of 5\% while foreign direct investment (FDI) and net official development assistance (ODA) proved to be important at a 5\% level. Trade liberalization (TRAD) also played an important role at the 5 percent level.

Moreso, the result was found to be highly positive relationship between the ODA (Other Development Asset) and the trade liberalisation of economy growth. As a result, a $1 \%$ rise in gross domestic product per person leads to an increase in net official developmental assistance (ODA) and trade liberalization (TRAD) of 12.5 percent and 125.45 percent, respectively. In addition, a 1 percent rise in the gross domestic product per capital contributed to a 17.2 percent decline in FDI. This corroborates the study conducted by Waweru \& Ochieng (2017). As part of our main contribution, what role does the trade liberalisation play in the capital inflows-economic growth nexus in Nigeria. Based on the literature, the component of capital flows identified and used in this study are FDITRAD, ODATRAD and REMTRAD. From model II, we observe that the interaction between capital inflows and trade liberalisation is positive for ODATRAD and negative for FDITRAD and are found to be statistically significant at 5 percent while REMTRAD was positive but insignificant, the positive nexus collaborates with the studies by Sakyi (2011), which also affirm the Bhagwati's, hypothesis whereas the negative relationship is also evidence of the studies conducted by Akinlo (2004); Shahbaz and Rahman (2010) but failed to align with Bhagwati's, hypothesis. By implication, the remittances received by REMTRAD have not been a conduit for the productive economic sector which can stimulate growth rather than likelihood that such remittances received were used for consumption purposes.

From model III, we observed that the results were significant at 5 percent except for the interactive behaviour of foreign direct investment and trade liberalisation on gross domestic product per capita. It was further observed that positive relationship exist between ODA and per capital GDP i.e. one percent increase in net official development assistance would result to an increase in per capita GDP by 15.7 percent. Similarly, one percent increase in REM and TRAD would bring about a percentage increase in per capita GDP by 24.78 and 25 percent respectively.

Equally, the interactive behaviour between ODATRAD and REMTRAD was found to exhibit a negative relationship and statistically significant. Thus, this implies that one percent increase in ODATRAD would results to one percent decrease 
S. Adegboyega, T. Akinbobola, F. Ajayi. Capital Flows and Economic Growth:

What Roles Does Trade Liberialisation Play?

in per capita GDP by 15.59 percent and similarly, one percent increase in REMTRAD would results to one percent decrease in per capita GDP.

\section{Cointegration Bound Test}

Therefore, autoregressive distributed lag model (ARDL) was employed to estimate the regression.

Table 4

\section{Results of ARDL Cointegration Test}

\begin{tabular}{|l|c|c|c|}
\hline Test Statistics & Value & Lower bound $@ \mathbf{5 \%}$ & Upper bound @5\% \\
\hline F-Statistic & $3.81872(0.0018)$ & 2.32 & 3.5 \\
\hline
\end{tabular}

Source: Authors' Computation (2019).

Table 4 displays the effects of the boundary checking co-integration. Due to the 2.32 and 3.50 lower and upper bond test statistics at 5\% significance, measured Fstatistics of 3.81872 are higher than the upper band test, which indicates that the variables in the model have a long-lasting relationship.

Table 5

\section{Statistical Output for the Short Run Estimate}

\begin{tabular}{|l|r|r|r|}
\hline \multicolumn{1}{|c|}{ Variable } & \multicolumn{1}{c|}{ Coefficient } & Std. Error & \multicolumn{1}{c|}{ t-Statistic } \\
\hline D(FDI) & 0.249985 & 0.183417 & 1.362931 \\
\hline D(FDITRAD) & -0.003818 & 0.002748 & -1.389623 \\
\hline D(FDITRAD(-1)) & 0.00013 & 0.000137 & 0.946438 \\
\hline DLOG(ODA) & 0.216041 & 0.08716 & 2.478659 \\
\hline DLOG(ODA(-1)) & -0.250403 & 0.086904 & -2.881384 \\
\hline D(ODATRAD) & 0.000000 & 0.000000 & -1.171459 \\
\hline D(ODATRAD(-1)) & 0.000000 & 0.000000 & 2.826502 \\
\hline D(REM) & -0.022491 & 0.066887 & -0.336249 \\
\hline D(REM(-1) $)$ & -0.064024 & 0.065465 & -0.977991 \\
\hline D(REMTRAD) & 0.000086 & 0.001015 & 0.084853 \\
\hline D(REMTRAD(-1)) & 0.001034 & 0.000856 & 1.207468 \\
\hline D(TLIB) & 0.020016 & 0.010056 & 1.990454 \\
\hline D(TLIB(-1)) & -0.018451 & 0.009298 & -1.984446 \\
\hline ECM(-1) & -1.137785 & 0.33378 & $-3.408786 *$ \\
\hline
\end{tabular}

Source: Author's computation (2019). 
Table 5 shows a negative and statistically important error correction coefficient at 5 percent significance point. This however indicates the existence of a short-run relationship in the model and shows that the pace of short-run change is 113.778 percent. On the one side, the existence of a large error term indicates that causality runs in at least one direction, which supports by Granger (1986) and similarly, Bannerjee et. al., (1998) noted that a highly significant error correction term signifies a stable long run relationship among variable of interest.

Table 6

Estimates of Long Run Coefficient using ARDL

\begin{tabular}{|l|r|r|r|}
\hline \multicolumn{1}{|c|}{ Variable } & \multicolumn{1}{c|}{ Coefficient } & \multicolumn{1}{c|}{ Std. Error } & \multicolumn{1}{c|}{ t-Statistic } \\
\hline C & -1.753949 & 0.666803 & $-2.630384 * *$ \\
\hline FDI & 0.828292 & 0.243118 & $3.406953 * *$ \\
\hline FDI*TRAD & -0.012336 & 0.003542 & $-3.483289 * *$ \\
\hline LODA & 0.276867 & 0.04461 & $6.206454 * *$ \\
\hline ODA*TRAD & 0.000000 & 0.00000 & $-2.714696 * *$ \\
\hline REM & -0.061669 & 0.06357 & -0.970093 \\
\hline REM*TRAD & 0.000945 & 0.000902 & 1.047683 \\
\hline TRAD & 0.052819 & 0.014944 & $3.534441 * *$ \\
\hline
\end{tabular}

Source: Author's Computation (2019).

** signifies $5 \%$ significant level

Table 6 shows that only remittances are not relevant among interested variables, even when they interacted with trade liberalisation in the long run. The implication of this could be attributed to the extent to which the funds are being put into and used by the recipients of such funds. However, foreign direct investment (FDI), net official developmental assistance (ODA) and trade liberalisation (TRAD) exhibits a positive relationship with economic growth and found to be statistically significant which is in line with the study conducted by Osinubi \& Amaghionyeodiwe (2010); Khadraoui (2012); Waweru \& Ochieng (2017). However, the interactive role between net official development assistance (ODA) and trade liberalisation (TRAD) shows positive and statistically significant relationships with economic growth, which supported the Bhagwati's hypothesis, while there are negative and statistically significant relationship between trade liberalisation and foreign direct investment. 
S. Adegboyega, T. Akinbobola, F. Ajayi. Capital Flows and Economic Growth:

What Roles Does Trade Liberialisation Play?

Table 7

\section{Statistical Output for Diagnostic Check}

\begin{tabular}{|c|c|c|}
\hline Test Name & F-Statistics & P-Value \\
\hline Normality & 18.145 & 0.0001 \\
\hline Serial Correlation LM & 1.19196 & 0.3665 \\
\hline ARCH test & 0.061861 & 0.8055 \\
\hline Heteroscedasticity & 0.229629 & 0.9968 \\
\hline
\end{tabular}

Source: Authors' Computation (2019).

The diagnostic test is presented in Table 7 and shows that the model is free of both serial correlation and heteroskedaticity problem.

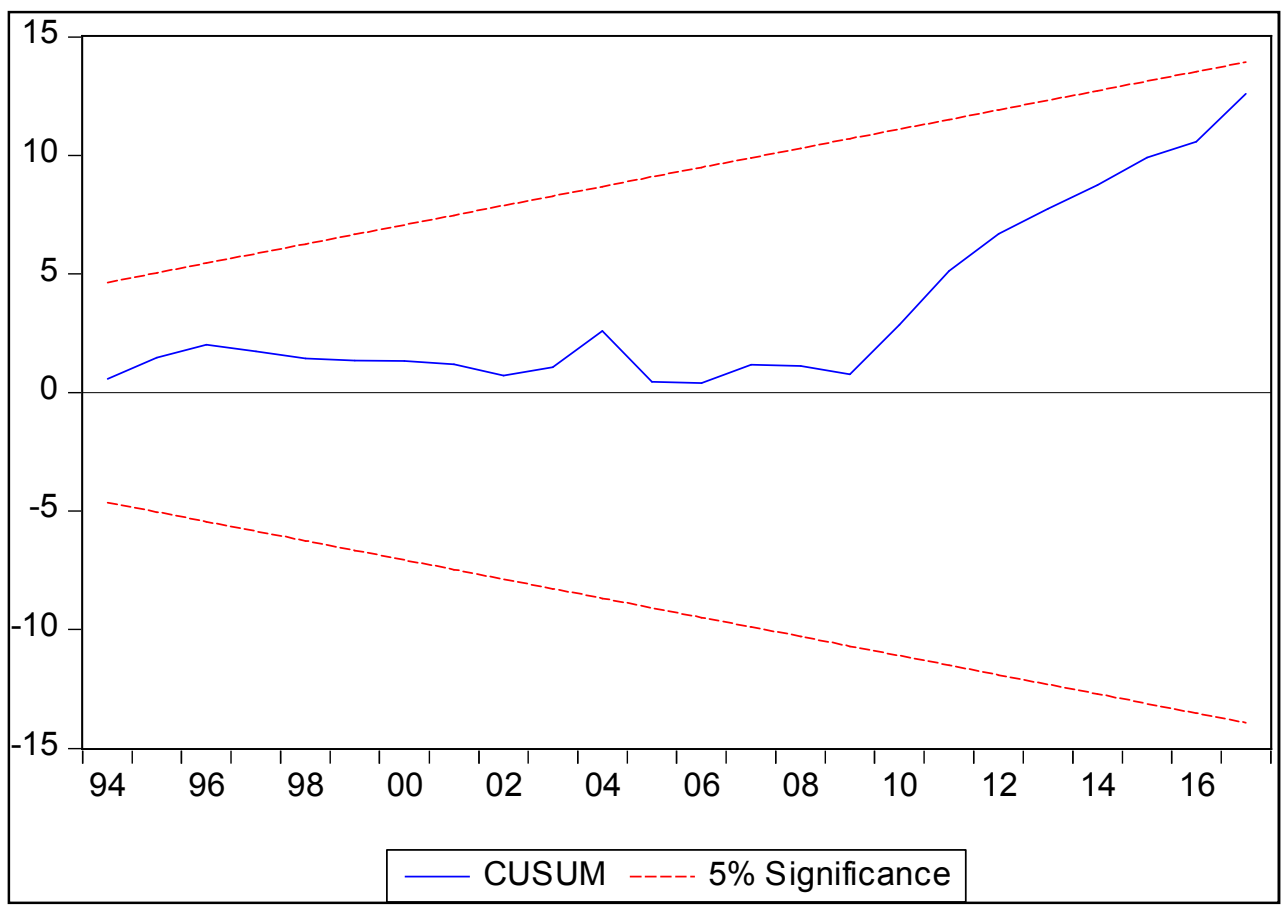

Figure 1. CUSUM Stability Test

The Ramsey reset test shows that the model has an error problem. However, as the blue line in Figure 5.1 is within the borders and does not override the critical 
boundaries, the CUSUM recursive test confirms a reasonably high degree of stability for the model relationship, which indicates that the model is correctly specified and the long-term coefficients are stable. Hence, the estimated models passed all diagnostic tests against heteroscedasticity (ARCH test), serial correlation (BreuschGodfrey test), normality (Jarque-Bera test), and function form errors (Ramsey regression equation specification error test (RESET)

In view of the above findings, we were able to establish that both private capital inflows and public capital inflows with the help of trade liberalisation inhibited economic growth in Nigeria. For examples, foreign direct investment (FDI), net official developmental assistance (ODA) and trade liberalisation (TRAD) exhibit a positive relationship with economic growth and found to be statistically significant. If trade liberalisation interacted only with net official development assistance is found to be positive, whereas trade liberalisation with foreign direct investment is found to be negative and statistically significant.

These outcomes are insightful because, even the one with positive coefficient do not enhance economic growth and by implication it shows that the various forms of trade liberalisation policy embark upon by the Nigeria government had not significantly attract more of the foreign capital inflows, which could be as a result of many factors among which are corruption, bureaucratic nature of government in the country etc.

Furthermore, when remittances and trade liberalisation were interacted, we found it to be insignificant. This only signal the fact that remittance received had not been channelled to the productive sector of the economy which ought to stimulate growth rather than probability, and those remittances received had been used for consumption purposes. Furthermore, we were able to corroborate partial Bhagwati's hypothesis in Nigeria which state that, any gains from capital inflows on TFP would surely be dependent on the volume of trade openness of a particular host country.

It is however, imperative that the Nigerian government should ensure that with its huge number of people residing outside the shore of Nigeria, the huge inflows of remittances need to be monitors and channels to productive sector of the economy so as to boost the economic activities of the country. Similarly, the government needs to restructure and re-engineer most of its trade policies, in order to significantly impact various forms of foreign capital inflows, and subsequently enhance economic growth by creating an enabling economic environment to facilitate adequate inflows of capital inflows. 
S. Adegboyega, T. Akinbobola, F. Ajayi. Capital Flows and Economic Growth: What Roles Does Trade Liberialisation Play?

\section{References}

1. Abdulai, A. \& Jaquet, P. (2002). Exports and Economic Growth: Cointegration and Causality Evidence for Cote d'Ivoire. African Development Review, 14(1), pp.1-17.

2. Adams, S. \& Klobodu, E.K.M. (2017). Capital flows and the distribution of income in subSaharan Africa. Economic Analysis and Policy, 55, pp.169-178.

3. Adegboyega, S.B, Odusanya, I. A. \& Popoola, R.O. (2017). Trade, Capital Flows and Economic Growth in Nigeria: Journal of Economic and Policy Analysis; (JEPA): 2(2), pp.236-250; University of Lagos, Akoka.

4. Aizenman, J. \& Noy, I. (2009). Endogenous Financial and Trade Openness. Review of Development Economics, 13,pp.175-189. https://doi.org/10.1111/j.14679361.2008.00488.x.

5. Akanyo, B. A. \& Ajie, H. A. (2015). Impact of capital flows on the Nigerian economy in a liberalized environment, International Journal of Business and Finance Management Research, pp.6-18.

6. Akinlo, A. E. (2004) Foreign direct investment and growth in Nigeria: An empirical investigation. Journal of Policy Modelling, Elsevier, 26(5), pp.627-639.

7. Alege, P. O. \& Ogun, T. P. (2005). Exploring the Globalization Industrialization Nexus for Economic Development: A Case of Nigeria, Selected Papers for the 2004 Annual Conference, Ibadan: Nigerian Economic Society, pp.245274.

8. Alfaro, L., Chanda, A, Kalimli-Ozcan \& Sayek, S. (2001). FDI and Economic Growth. The Role of Local Financial Market. Journal of international economic 64, pp.113-134.

9. Asiedu, E. (2002) On the Determinants of Foreign Direct Investment to Developing Countries.- Is Africa different? World Development,30(1), pp.107-129.

10. Balasubramanyam, V.N., Salisu, M. A. \& Sapsford, D. (1996). Foreign direct investment and growth in EP and IS countries. The Economic Journal, 106, pp.92-105.

11. Barro, R. J. \& Sala-I-Martin, X. (1995). Capital mobility in neoclassical models of growth. American Economic Review, 85, pp.103-115.

12. Barro, R. J. (1991). Economic growth in cross section of countries. Quarterly Journal of Economics, 106, pp.407-444.

13. Bannerjee, A. Dolado, J. \& Mestre, R. (1998). Error correction mechanism tests for cointegration in the single equation framework. Journal of Time Series Analysis, 19, pp.267-283. 
14. Bhagwati, J. N. (1985). Investing Abroad; Esmee Fair bain Lecture, Lancaster University. Reprinted in V.N. Balasubramanyam (ed) J N Bhagwati, Writings on International Economics (1997), Delhi, Oxford University Press).

15. Borensztein, E. De Gregorio, J. \& Lee, J. W. (1998). How does Foreign Direct InvestmentAffect Economic Growth? Journal of International Economics, 45, pp.115-135.

16. Brun, Jean-François \& Sèna Kimm Gnangnon (2017). Does Trade Openness contribute to driving Financing Flows for Development? WTO Working Paper ERSD-2017-06.

17. Burke, P. J. \& Ahmadi-Esfahani, F. Z. (2006). Aid and Growth: A study of South-East Asia. Journal of Asian Economics 17, pp.350-362.

18. De Mello, L. R. Jr (1999). Foreign direct investment-led growth evidence from time series and panel data. Oxford Economics Papers, 51, pp.133-151

19. Engle, R. F. \& Granger, C.W.J. (1987). Co-Integration and Error Correction: Representation, Estimation, and Testing. Econometrica 55, pp.251-276.

20. Fayissah, B. \& Nsiah, C. (2010). The impact of governance in economic growth: Further evidence for Africa. Middle Tennessee State University Department of Economics and Finance Working Paper Series, December

21. Feder, G. (1983). On Exports and Economic Growth. Journal of Development Economics, 12, pp.59-73.

22. Fosu, A. K. (1990). Export Composition and the Impact of Exports on Economic Growth of Developing Economies. Economic Letters, 34, pp.67-71.

23. Granger, C. W. J. (1986). Development in the study of cointegration economic variable. Oxford Bulletin of Economics and Statistics 48, pp.213-228.

24. Grossman, G. \& Helpman, E. (1991). Innovation and Growth in the Global Economy. Cambridge: MIT Press.

25. Hassen, S. \& Anis, O. (2012). Foreign direct investment and economic growth: An approach in terms of cointegration for the case of Tunisia. J. Appl. Finance. Bank. 2(4), pp.193-207.

26. Kendrick, J. W. (1993). How much does capital explain? In A. Szirmai, B. Van Ark \& D. Pilat (Eds.), Explaining Economic Growth. Essays in Honour of Angus Maddison. Amsterdam: North Holland. pp.129-146.

27. Khaddraoui, N. (2012). Capital Movements and Economic Fluctuations: The Threshold Effects of Financial Development. International Journal of Economics and Finance. 4, pp.193-205.

28. Kormendi, R. C. \& Meguire, P. G. (1985). Macroeconomic determinants of growth: Cross-country evidence. Journal of Monetary Economics, 16, pp.141-163. 
S. Adegboyega, T. Akinbobola, F. Ajayi. Capital Flows and Economic Growth: What Roles Does Trade Liberialisation Play?

29. Mansouri, B. (2005). The interactive impact of FDI and trade openness on economic growth: Evidence from Morocco. 12th Economic Research Forum's Annual Conference, Cairo, Egypt.

30. Levine, R. \& Renelt, D. (1992). A sensitivity analysis of cross-country regressions. The American Economic Review, 82(4), pp.942-963.

31. Lipsey, R. E. (2000). Inward FDI and economic growth in developing countries. Transnational Corporations, 9, pp.61-95.

32. Lucas, R. E. (1988). On the mechanics of economic development. Journal of Monetary Economics, 22(1), pp.32-42.

33. Mowlaei, M. (2018). The impact of foreign capital inflows on economic growth on selected African countries. African Journal of Economic and Management Studies, 9(4), pp.523-536.

34. Odhiambo, N. M. (2011). Financial Deepening, Capital Flows and Economic Growth Nexus in Tanzania: A Multivariate Model. Journal of Social Sciences 28(1), pp.65-71.

35. Okore, O. A. \& Onoh, J. O. (2013). The impact of capital account liberalization on economic growth in Nigeria. European J. Bus. Manage. ISSN 22222839, 5:34.

36. Olaleye, S. O. (2015). Impact of Capital Flows on Economic Growth in Nigeria, International Journal of Economics, Commerce and Management U.K 3(5), pp.1285-1304.

37. Orji, A., Uche, A. S, \& Ilori, E. A. (2014). Foreign Capital Inflows and Growth: An Empirical Analysis of WAMZ Experience International Journal of Economics and Financial. 4(4), pp.971-983.

38. Osinubi, T. S. \& Amaghionyeodiwe, L. A. (2010). Foreign Private Investment and Economic Growth in Nigeria. Review of Economics and Business Studies, 3(1), pp.105-127.

39. Pagano, M. (1993). Financial markets and growth: An overview. European Economic Review, 37, pp.613-622.

40. Pahlavani, M., Wilson, E. \& Worthington, A. C. (2005). Trade-GDP nexus in Iran: An application of autoregressive distributed lag (ARDL) model. American Journal of Applied Science, 2, pp.1158-1165.

41. Paugel, A.T. (2007). International Economics. McGraw-Hill Irwin: New York, USA.

42. Pesaran, H. M. \& Shin, Y. (1995). Long-Run Structural Modelling. Cambridge Working Papers in Economics Number 9419. 
43. Pesaran, M. H., Shin, Y. \& Smith, R.J. (2001). Bounds testing approaches to the analysis of level relationships. Journal of Applied Econometrics, 16, pp.289-326.

44. Pesaran, M. H. \& Shin, Y. (1999). An Autoregressive Distributed Lag Modelling Approach to Cointegration Analysis. In S. Strom (Ed.), Econometrics and Economic Theory in 20th Century:The Ragnar Frisch Centennial Symposium, Chapter 11. Cambridge University Press.

45. Sakyi, D. (2011). Trade Openness, Foreign aid and Economic Growth in Post-liberalization Ghana: An Application of ARDL Bounds Test. Journal of Economics and International Finance, 3(3), pp.146-156.

46. Shahbaz, M. \& Rahman, M.M. (2010). Foreign capital inflows-growth nexus and role of domestic financial sector: an ARDL cointegration approach for Pakistan. Journal of Economic Research, 15(3), pp.207-231.

47. Shuaib, O. M. (2014). Capital Inflow and Economic Growth Nexus in Nigeria: The Role of Trade Openness. Acta Universitatis Danubius. 10(6), pp.99-113.

48. Uwatt, B. U. (2004). Globalization and Economic Growth: The African Experience, Globalization and Africa's Economic Development, Ibadan, Nigerian Economic Society, pp.129-158.

49. Waweru, G. \& Ochieng, D. E. (2017). Effects of capital flows on economic growth in Kenya. African Development Finance Journal (ADFJ), 1(2), pp.1-17.

50. Xu, B. (2000). Multinational enterprises, technology diffusion and host country productivity growth. Journal of Development Economics, 62, pp.477-493. 